\title{
Australian immigration detention and the silencing of practitioners
}

\author{
April Pearman, B.PSYCH, BA*, Stephanie Olinga-Shannon, BAPS/BA (Hons),*
}

In recent years, the Australian Government has framed the arrival of asylum seekers by boat as a national security risk and the policy of stopping 'unauthorised maritime arrivals' has been used extensively by various political parties in their election campaign platforms (Phillips, 2017). Media coverage has reinforced this framing with the portrayal of asylum seekers arriving by boat as economic migrants and threats to Australian society and security (Blood, 2011; Bleiker et al, 2013). The Australian Border Force Act 2015 (the Act) merged the immigration and customs department and introduced weapons and uniforms for some employees. Importantly, the Act also introduced secrecy provisions that are further eroding the humanitarian response to asylum seekers. Whilst the restrictions with respect to health professionals have now been lifted, the attempt to effectively gag workers who witness conditions in places of detention still begs the question: why the lack of transparency?

Under the 'secrecy provisions' of the Act, 'entrusted persons' (any persons employed by the Department of Immigration and Border Protection (DIBP) or subcontracting to the department) who disclose 'protected information' (any information obtained in

*) Association for Services to Torture and Trauma Survivors (ASeTTS), Perth, Australia. their capacity as an 'entrusted person') can face criminal conviction and a maximum of two years imprisonment (Australian Border Force Act, 2015). The law applies to immigration detention centres both on the Australian mainland (known as onshore immigration detention centres) and those centres in Papua New Guinea, Nauru and on Christmas Island that house asylum seekers who were attempting to reach the Australian mainland by boat (known as offshore immigration detention centres). Under the Act, entrusted persons are able to report any incidents to the DIBP officials and it is assumed that this will be sufficient in fulfilling any ethical or professional reporting obligations. Health professionals, including ASeTTS' counselling staff, were included in this category from 1 July 2015 until September 2016, at which point the government quietly changed the law to avoid further detrimental publicity. However, it remains in force for teachers, social workers not working as counsellors, and other professionals working in immigration detention centres.

Prior to the introduction of the Act, all staff working in detention centres were able to advocate for the needs of their clients inside detention centres, to DIBP officials, as well as more widely. Clearly, this is necessary to avoid potential abuse of individuals and human rights violations 
(witnessed or reported), as well as to allow for mandatory reporting issues or whistle-blower situations. Assaults and deaths of asylum seekers in immigration detention centres are known to have occurred (Australian Human Rights Commission 2014, Procter et al 2013). Crucially, practitioners and others have been able to provide important information to the Australian public about the living conditions, treatment of asylum seekers and incidents of violence in immigration detention centres as well as to the Australian Senate, United Nations and Human Rights Commission inquiries and the media, amongst others. This is of particular importance as immigration detention centres in Australia are often located in extremely remote areas with limited public access and as the Australian Government releases limited information about the centres beyond a monthly statistical report detailing the number of detainees, their basic demographic information and the duration of their detention in these centres (see DIBP, 2017a). Information provided by practitioners is therefore not only important with respect to the individual protection of asylum seekers, but also for accountability and the improvement of public policy. With information restricted beyond the walls of the detention centres, harmful events can be covered up: there is a significant risk created by the 'blind spots' in transparency and accountability created in the name of 'border control'.

\section{Impact on health professionals everyday work and research}

Immigration detention has always been a very challenging work environment for practitioners. Ethical and boundary dilemmas are a constant feature of this working context. To witness daily the plight of asylum seekers is devastating, with the average period of time for people held in immigration detention centres currently 440 days (DIBP, 2017b). For practitioners, to assist detainees in regards to their traumatic pasts, whilst being acutely aware of their current life challenges, including a highly triggering environment, which is counterproductive for trauma recovery can feel like the provision of a sub-standard service. This is not unlike the practice of doctors in wars patching up troops to send them back out to battle. Counsellors can have feelings of guilt when leaving the centre each day, in full knowledge that their clients do not currently share the same human right. The Act added another layer on top of these existing dynamics, making work in immigration detention even more complex, as it criminalised actions that were previously viewed as appropriate professional behaviour.

The Act left health practitioners in a double-bind. In Australia, as elsewhere, psychologists and counsellors register with professional associations that monitor their professional conduct. Registered psychologists adhere to the Australian Psychological Society (APS) Codes of Ethics and must, for example, report to the relevant authorities criminal activity or the abuse of minors (Australian Psychosocial Society, 2007). If they do not, they can face professional investigation with consequent de-registering from their professional body or face a criminal conviction with a maximum two years' imprisonment. However, under the Act, psychologists were unable to report to anybody other than the DIBP. If a psychologist reported, for example, abuse to the police, they could therefore have faced two years' improsonment and a criminal conviction under the Act. A criminal conviction can also have ramifications for future employment, travel and residency in 
Australia and overseas. Under Austrialian law, a conviction of one year's imprisonment or more may result in deportation for practitioners who are not Australian citizens, even if they hold permanent Australian residency, and potential loss of registration. The potential penalty imposed under the Act can therefore prevent practitioners from speaking publicly about the situation or treatment of asylum seekers in immigration detention centres.

The Act also impacted the effectiveness of advocacy and research carried out by health professionals. ASeTTS and other rehabilitation centres draw on staff's experiences inside immigration detention centres for submissions into public inquiries, such as, the Australian Human Rights Commission's 2014 National Enquiry into Children in Immigration Detention and various consultations on asylum seeker wellbeing. Whilst ASeTTS could and did continue to support asylum seekers rights publicly, it was no longer possible to draw on practitioner experiences inside immigration detention for advocacy work whilst the Act was in place. The Act functioned as a 'gag order' for service providers, advocates and researchers.

It was unclear whether data collated in immigration detention could be shared with research partners and ultimately in publicly available research. Large datasets of mental health assessments collected inside immigration detention centres are rare but necessary to inform evidence-based public policy decisions relating to asylum seekers (Killedar and Harris, 2017). For ASeTTS, publishing such research is of course intended to inform and influence public policy and is integral to broader systemic advocacy for the needs and rights of clients. As it was a new law, there is no legal precedent, so for the first time, practitioners, organisations and university researchers had to consider the legal implications of making information public. This had a direct impact on slowing down research projects and information dissemination plans. Furthermore, the law targeted individuals so there was combined personal and organisational risks associated with operating in a manner that was considered ethical prior to the introduction of this new legal framework.

\section{Reaction to the Act}

The introduction of the Border Force Act was met by a significant public outcry from relevant professional associations and their members such as the APS, Australian Association of Social Workers (AASW) and the Australian Medical Association (AMA). These groups protested against the law and engaged in various forms of opposition via public statements, public protest, and in some instances, doctors refusing to release patients from hospitals back to immigration detention centres (Dudley, 2016). The AMA led the legal fight against the Border Force Act in the High Court of Australia. A few days before the case was to be heard, the Australian Government decided to legally settle with the AMA, and exempt 'health professionals' rather than have the case heard in the High Court, which would have exposed the design process of the law (Hall, 2016). The Border Force Act was deliberately quietly amended to exempt 'health professionals' with minimal communications regarding the amendment and provoked limited media attention.

This episode, although thankfully shortlived for health professionals, made us and other practitioners question the boundaries of whether ethical services can continue to be delivered under such circumstances. More importantly perhaps, it underlines the 
importance of being able to speak publicly about what is seen or heard in immigration detention. Although the exemption granted to health practitioners occurred in September 2016, the issue remains for practitioners who are not exempt, such as social workers. That such a law was possible in a liberal democracy such as Australia exemplifies the erosion of ethics in immigration and sets a dangerous precedent for other countries (Jakubowicz, 2016). The Border Force Act was passed with support from the opposition, Australia's other major party the Australian Labour Party (ALP) (known as bi-partisan support). This signals that, even if a different government takes power, the Act is unlikely to change. The law is a further example of the 'race to the bottom' for other democratic countries at a time when there are more people seeking asylum globally than ever before (UNHCR, 2017). What is perhaps even more disturbing, the Act echoes the same degradation of human rights and practice of silencing as the regimes from which refugees are escaping.

\section{References}

Australian Human Rights Commission. (2014). The Forgotten Children. The National Enquiry to Children in Immigration Detention. Sydney.

Australian Psychological Society. (2007). Code of Ethics. Melbourne, Victoria.

Bleiker, R., Campbell, D., Hutchison, E. \& Nicholson, X. (2013). The visual dehumanisation of refugees. Australian Fournal of Political Science, 48(4) 398-416.

Department of Immigration and Border Protection (DIBP). (2017a). Immigration Detention Statistics. Retrieved from https://www.border.gov.au/about/ reports-publications/research-statistics/statistics/ live-in-australia/immigration-detention

Department of Immigration and Border Protection (DIBP). (2017b). Immigration Detention and Community Statistics Summaries: 30 September 2017. Retrieved from https://www.border.gov.au/ ReportsandPublications/Documents/statistics/ Immigration-detention-statistics-30-september-2017.pdf
Dudley, M. (2016). Helping professionals and Border Force secrecy: Effective asylumseeker healthcare requires independence from callous policies. Australasian Psychiatry, 24(1), 15-18. https://doi. org/10.1177/1039856215623354

Hall B. (2016). 'A huge win for doctors': Turnbull government backs down on gag laws for doctors on Nauru and Manus. The Sydney Morning Herald. Sydney.

Jakubowicz, A., (2016) European leaders taking cues from Australia on asylum seeker policies. The Conversation. 7 November.

Killedar, A., \& Harris, P. (2017). Australia's refugee policies and their health impact: a review of the evidence and recommendations for the Australian Government. Australian and New Zealand fournal of Public Health, 41(4), 335-337. https://doi. org/10.1111/1753-6405.12663

Blood, R. (2011). "Any one of these boat people could be a terrorist for all we know!” Media representations and public perceptions of "boat people" arrivals in Australia. Fournalism, 12(5), 607626. https://doi.org/10.1177/1464884911408219

Phillips J. (2017). A comparison of Coalition and Labor government asylum policies in Australia since 2001. In: Library P (ed) Research Paper Series 2016-17. Canberra: Parliament of Australia, Department of Parliamentary Services.

Procter, N.G., De Leo, D. \& Newman, L. (2013). Suicide and self-harm prevention for people in immigration detention. Medical fournal of Australia, 199 (11) 730-732. https://doi.org/10.5694/ mja13.10804

UN High Commissioner for Refugees (UNHCR) (2017). Global Trends: Forced Displacement in 2016. 